\title{
Zinc Finger Protein ZIC 3
}

National Cancer Institute

\section{Source}

National Cancer Institute. Zinc Finger Protein ZIC 3. NCI Thesaurus. Code C75544.

Zinc finger protein ZIC 3 (467 aa, $51 \mathrm{kDa}$ ) is encoded by the human ZIC3 gene. This protein is involved in transcriptional regulation. 